\title{
Perinatal and neonatal outcome in meconium stained amniotic fluid
}

\author{
Shazia Qadir ${ }^{1}$, Sami Jan ${ }^{1}$, Javaid A Chachoo ${ }^{2}$, Shameem parveen ${ }^{1}$
}

\author{
${ }^{1}$ Department of Obstetrics and Gynaecology, Sher-i-Kashmir Institute of Medical Sciences, Soura, Srinagar, India \\ ${ }^{2}$ Department of Medicine Government Medical College, Karan Nagar, Srinagar, Kashmir, India
}

Received: 19 January 2016

Revised: 31 January 2016

Accepted: 01 March 2016

\author{
*Correspondence: \\ Dr. Javaid A Chachoo, \\ E-mail: drjavaid_c@yahoo.com
}

Copyright: (C) the author(s), publisher and licensee Medip Academy. This is an open-access article distributed under the terms of the Creative Commons Attribution Non-Commercial License, which permits unrestricted non-commercial use, distribution, and reproduction in any medium, provided the original work is properly cited.

\begin{abstract}
Background: Meconium passage in new born is a developmentally programmed event normally occurring within the first 24 to 48 hours after birth. Intrauterine meconium passage in near-term or term fetuses has been associated with fetomaternal stress factor like hypoxia and infection independent of fetal maturity. The incidence of meconium stained amniotic fluid is $1-18 \%$. The objective of this study was to correlate the presence of meconium in amniotic fluid with perinatal outcome.

Methods: A total of 300 women were taken in the study, out of which 54 cases who were found to have meconium on spontaneous or artificial rupture of membranes were monitored with fetal heart rate abnormalities, 5 minute APGAR score and neonatal complications as outcome variables.

Results: The incidence of meconium stained liquor was $18 \%$.Fetal heart rate abnormalities were seen more often with thick meconium $(62.5 \%)$ than with thin meconium (15.8\%) which was statistically significant. In the present study there was a good correlation between APGAR score and MAS, 3 neonates with thick meconium in the severely asphyxiated group had MAS. No babies with APGAR $>7$ had MAS. Neonatal morbidity due to MAS was seen in 3 $(18.8 \%)$ cases and mortality was seen in $4(7.41 \%)$ cases.

Conclusions: The significance of meconium in amniotic fluid is a widely debated subject. Traditionally meconium has been considered as a sign of fetal distress occurring due to hypoxia. However it is now recognized as a manifestation of a normally maturing gastrointestinal tract. In a global sense it is still considered a marker for adverse perinatal outcomes. The presence of thick meconium is associated with increase in the perinatal morbidity and mortality and hence its presence should not be overlooked.
\end{abstract}

Keywords: Meconium stained amniotic fluid, Meconium aspiration syndrome, Thick meconium

\section{INTRODUCTION}

Meconium passage in new born is a developmentally programmed event normally occurring within the first 24 to 48 hours after birth. Intrauterine meconium passage in near-term or term fetuses has been associated with fetomaternal stress factor like hypoxia and infection independent of fetal maturity. The incidence of meconium stained amniotic fluid is $1-18 \% .^{1}$ In the past, meconium stained liquor was considered as a sign of fetal distress. However, it is now recognized that in the majority of cases meconium passage is a manifestation of a maturing gastrointestinal tract or is the result of vagal stimulation due to umbilical cord compression. Although intestinal meconium appears very early in gestation meconium stained amniotic fluid rarely occurs before 38 weeks gestational age. An association among meconium stained liquor, fetal compromise and perinatal morbidity is well known .However, most of the infants with meconium in liquor do not have low APGAR, more 
acidosis or clinical illness than infants born with clear amniotic fluid. Thus the neonatal outcome in meconium stained liquor is generally comparable to deliveries with clear amniotic fluid, when the fetal heart rate is normal. Perinatal morbidity is increased in new born with abnormal fetal heart rate. Hence the presence of meconium in liquor calls for continuous fetal heart rate monitoring/fetal blood sampling. ${ }^{2,3}$ Meconium aspiration syndrome (MAS) occurs in approximately $35 \%$ of live births with meconium stained liquor. ${ }^{4}$ Aspiration of the meconium into fetal or neonatal lungs is associated with clinical disease ranging from mild respiratory distress to severe respiratory compromise and causes significant increase in perinatal morbidity and mortality. ${ }^{5}$

The present study was designed to study the clinical correlation of neonatal outcome with meconium stained amniotic fluid. Relationship of meconium stained amniotic fluid with CTG abnormalities and mode of delivery was also studied.

The objective of this study was clinical correlation of neonatal outcome with meconium stained amniotic fluid, to study the mode of delivery in meconium stained amniotic fluid, and to study relation between meconium staining and fetal heart rate variability.

\section{METHODS}

A prospective study of 300 cases was done between July, 2013 to June 2015 at obstetrics and gynecology department of Sher-i-Kashmir Institute of Medical Sciences, Soura, Srinagar, Kashmir, India. All laboring women with singleton pregnancy at term with cephalic presentation were found to have meconium on either spontaneous/artificial rupture of membranes, were enrolled for the study after obtaining written and informed consent. Patient particulars were noted down with regard to obstetric history, cervical dilatation and the fetal heart rate pattern were recorded. Meconium was graded as "thin" if there was very light green staining of amniotic fluid and "thick" if the fluid was viscous, tenacious and contained large amount of particulate material. The mode of delivery and the neonatal APGAR score at 5 minutes were recorded. Laryngoscopic examination was done in depressed babies. If meconium was present below the vocal cord, then endotracheal suctioning was done. The neonate was followed up during their stay in the hospital.

\section{Statistical method}

It is a descriptive study to see different outcome of MSAF. All the categorical variables were analyzed with the help of chi square test and Fisher's exact test and all the continuous variables were analyzed with the independent $t$ test. All the statistical results are discussed with $5 \%$ level of signifance i.e $\mathrm{p}$ value $<0.05$ will be considered significant.

\section{RESULTS}

The data collected in this study in 300 patients is presented in the following tables/graphs.

Table 1: Incidence of MSAF.

\begin{tabular}{|lll|}
\hline MSAF (cases) & NMSAF (controls) & Total \\
\hline 54 & 246 & 300 \\
\hline
\end{tabular}

Out of 300 patients selected for the present study which had inclusion criteria, $18 \%$ were meconium stained out of which 38 cases had thin meconium and 16 cases had thick meconium.

Table 2: FHR abnormality in different groups.

\begin{tabular}{|c|c|c|c|c|}
\hline \multirow{2}{*}{$\begin{array}{l}\text { FHR } \\
\text { abnormal- } \\
\text { lity }\end{array}$} & \multicolumn{2}{|c|}{ Status } & \multirow[b]{2}{*}{$\begin{array}{l}\text { Total } \\
(\mathrm{n}=\mathbf{3 0 0})\end{array}$} & \multirow[b]{2}{*}{$\begin{array}{l}P \\
\text { value }\end{array}$} \\
\hline & $\begin{array}{l}\text { Cases } \\
(\mathrm{n}=54)\end{array}$ & $\begin{array}{c}\text { Controls } \\
\text { (246) }\end{array}$ & & \\
\hline Present (\%) & $16(29.6 \%)$ & $23(9.3 \%)$ & $39(13 \%)$ & $<0.001$ \\
\hline
\end{tabular}

Fetal CTG abnormalities were more common in MSAF group and were noted in $29.6 \%$ of cases which is significantly increased compared to control group with CTG abnormalities in $9.3 \%$. The difference was significant with $\mathrm{p}$ value of $<0.001$.

Table 3: FHR abnormality in cases.

\begin{tabular}{|c|c|c|c|c|}
\hline \multirow{2}{*}{$\begin{array}{l}\text { FHR } \\
\text { abnormal- } \\
\text { lity }\end{array}$} & \multicolumn{2}{|c|}{ Cases (MSAF) } & \multirow{2}{*}{$\begin{array}{l}\text { Total } \\
(\mathrm{n}=54)\end{array}$} & \multirow{2}{*}{$\begin{array}{c}\mathbf{P} \\
\text { value }\end{array}$} \\
\hline & Thin & Thick & & \\
\hline Present (\%) & $\begin{array}{l}6 \\
(15.8 \%)\end{array}$ & $\begin{array}{l}10 \\
(62.5 \%)\end{array}$ & $\begin{array}{l}16 \\
(29.6 \%)\end{array}$ & \multirow[t]{2}{*}{$\begin{array}{l}0.00 \\
1\end{array}$} \\
\hline Absent & $\begin{array}{l}32 \\
(84.2 \%)\end{array}$ & $\begin{array}{l}6 \\
(37.5 \%)\end{array}$ & $\begin{array}{l}38 \\
(70.4 \%)\end{array}$ & \\
\hline
\end{tabular}

Comparing the subgroups of thick and thin meconium among the cases, it was the thick subgroup which showed more frequent FHR abnormalities. The most common CTG abnormality noted was Variable deceleration.

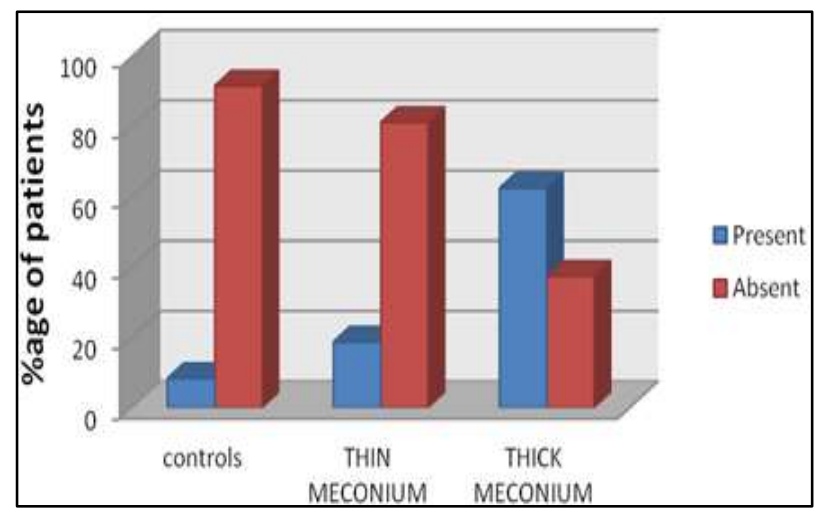

Figure 1: FHR Abnormality in different groups. 
Table 4: Mode of delivery.

\begin{tabular}{|c|c|c|c|c|}
\hline \multirow{2}{*}{$\begin{array}{l}\text { Mode of } \\
\text { delivery }\end{array}$} & \multicolumn{2}{|c|}{ Status } & \multirow{2}{*}{$\begin{array}{l}\text { Total } \\
(n=300)\end{array}$} & \multirow{2}{*}{$\begin{array}{c}\mathbf{P} \\
\text { value }\end{array}$} \\
\hline & $\begin{array}{l}\text { Cases } \\
(\mathrm{n}=54)\end{array}$ & $\begin{array}{c}\text { Controls } \\
\text { (246) }\end{array}$ & & \\
\hline $\begin{array}{l}\text { Normal } \\
\text { vaginal }\end{array}$ & $\begin{array}{l}25 \\
(46.3 \%)\end{array}$ & $\begin{array}{l}160 \\
(65.0 \%)\end{array}$ & $\begin{array}{l}185 \\
(61.7 \%)\end{array}$ & \multirow{3}{*}{0.037} \\
\hline $\begin{array}{l}\text { Asst. } \\
\text { vaginal }\end{array}$ & $\begin{array}{l}7 \\
(13.0 \%)\end{array}$ & $\begin{array}{l}21 \\
(8.5 \%)\end{array}$ & $\begin{array}{l}28 \\
(9.3 \%)\end{array}$ & \\
\hline LSCS & $\begin{array}{l}22 \\
(40.7 \%)\end{array}$ & $\begin{array}{l}65 \\
(26.4 \%)\end{array}$ & $\begin{array}{l}87 \\
(29.0 \%)\end{array}$ & \\
\hline
\end{tabular}

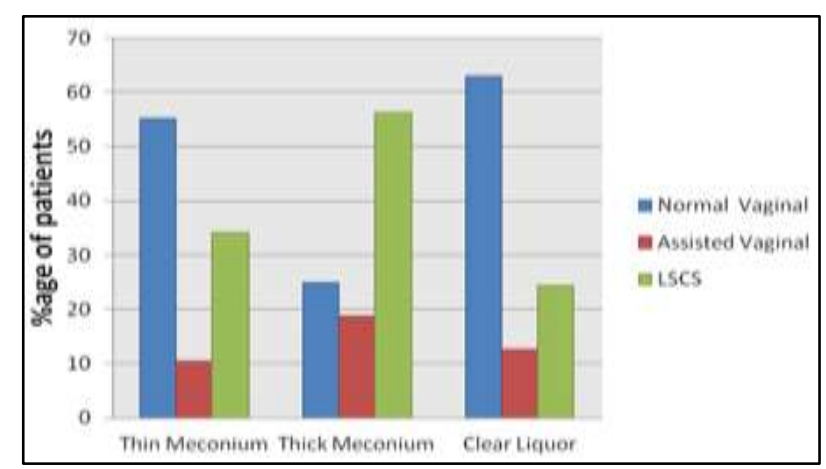

Figure 2: Mode of delivery.
25(46.3\%) patients with meconium stained amniotic fluid had normal vaginal delivery, while in control group out of 246, $160(61.7 \%)$ delivered normally. Incidence of LSCS and assisted vaginal delivery was more in meconium stained amniotic fluid.

Table 5: Mode of delivery in MSAF cases.

\begin{tabular}{|c|c|c|c|c|}
\hline \multirow[b]{2}{*}{$\begin{array}{l}\text { Mode of } \\
\text { delivery }\end{array}$} & \multicolumn{2}{|c|}{ Cases $(n=54)$} & \multirow[b]{2}{*}{$\begin{array}{l}\text { Total } \\
(\mathrm{n}=54)\end{array}$} & \multirow[b]{2}{*}{$\begin{array}{l}P \\
\text { value }\end{array}$} \\
\hline & $\begin{array}{l}\text { Thin } \\
(\mathrm{n}=38)\end{array}$ & $\begin{array}{l}\text { Thick } \\
(\mathrm{n}=16)\end{array}$ & & \\
\hline $\begin{array}{l}\text { Normal } \\
\text { vaginal }\end{array}$ & $\begin{array}{l}21 \\
(55.3 \%)\end{array}$ & $\begin{array}{l}4 \\
(25.0 \%)\end{array}$ & $\begin{array}{l}25 \\
(46.3 \%)\end{array}$ & \multirow{3}{*}{0.125} \\
\hline $\begin{array}{l}\text { Asst. } \\
\text { vaginal }\end{array}$ & $\begin{array}{l}4 \\
(10.5 \%)\end{array}$ & $\begin{array}{l}3 \\
(18.8 \%)\end{array}$ & $\begin{array}{l}7 \\
(13.0 \%)\end{array}$ & \\
\hline LSCS & $\begin{array}{l}13 \\
(34.2 \%)\end{array}$ & $\begin{array}{l}9 \\
(56.2 \%)\end{array}$ & $\begin{array}{l}22 \\
(40.7 \%)\end{array}$ & \\
\hline
\end{tabular}

On comparing the subgroups of thick and thin meconium, it was the thick group where operative intervention was more commonly needed. The difference between subgroups is insignificant with $\mathrm{p}$ value of 0.125 . Relatively higher $\mathrm{p}$ value is due to low number of cases in thick subgroup.

Table 6: Meconium first observed and mode of delivery.

\begin{tabular}{|c|c|c|c|c|c|}
\hline \multirow{2}{*}{$\begin{array}{l}\text { Labour Stage at meconium } \\
\text { detection }\end{array}$} & \multirow{2}{*}{$\begin{array}{l}\text { Type of } \\
\text { meconium }\end{array}$} & \multirow{2}{*}{ No. of cases } & \multicolumn{3}{|c|}{ Mode of delivery } \\
\hline & & & Vaginal delivery & Asst. vaginal & LSCS \\
\hline \multirow{2}{*}{ Latent phase } & Thin & 17 & 8 & 2 & 7 \\
\hline & Thick & 8 & 1 & 1 & 6 \\
\hline \multirow{2}{*}{ Active phase } & Thin & 13 & 8 & 1 & 4 \\
\hline & Thick & 5 & 2 & 1 & 2 \\
\hline \multirow{2}{*}{$2^{\text {nd }}$ Stage } & Thin & 8 & 5 & 1 & 2 \\
\hline & Thick & 3 & 1 & 1 & 1 \\
\hline
\end{tabular}

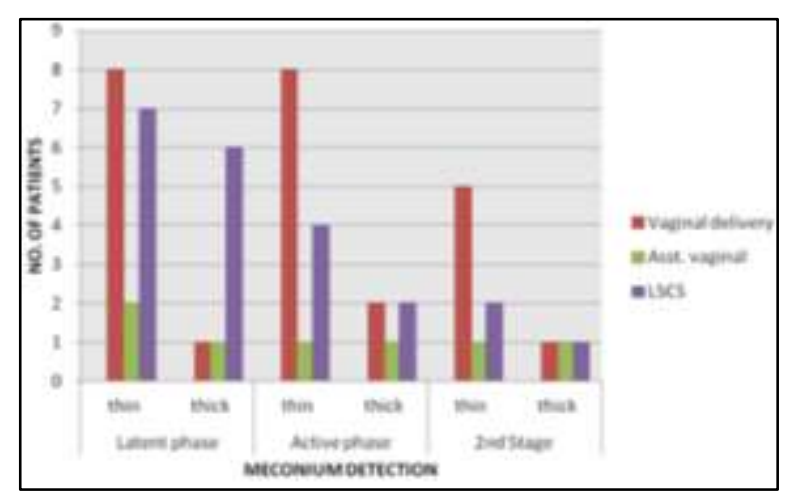

Figure 3: Meconium first observed and mode of delivery.

Low Apgar Score at 1 and 5 minutes was more prevalent in MSAF compared to control with $\mathrm{p}$ value of $<0.001$. At
1 minute the low APGAR score was noted in $38.9 \%$ of MSAF cases. At 5 minutes, the low APGAR score cases reduced to $20.4 \%$ but was much higher than controls with strong statistical significance.

Incidence of LSCS was more in meconium stained amniotic fluid if the meconium first appeared in latent phase and least if meconium appeared in $2^{\text {nd }}$ Stage. Moreover the LSCS incidence was much higher if the meconium was thick irrespective of stage.

Low Apgar Score at 1 and 5 minutes was more prevalent in MSAF compared to control with $\mathrm{p}$ value of $<0.001$. At 1 minute the low APGAR score was noted in $38.9 \%$ of MSAF cases. At 5 minutes, the low APGAR score cases reduced to $20.4 \%$ but was much higher than controls with strong statistical significance. 
Table 7: APGAR Score at 1 and 5 minutes.

\begin{tabular}{|c|c|c|c|c|}
\hline \multirow{2}{*}{$\begin{array}{l}\text { APGAR } \\
\text { score at } 1 \\
\text { minute }\end{array}$} & \multicolumn{2}{|l|}{ Status } & \multirow[b]{2}{*}{ Total } & \multirow{2}{*}{$\begin{array}{l}\mathbf{P} \\
\text { value }\end{array}$} \\
\hline & $\begin{array}{l}\text { Cases } \\
(\mathrm{n}=54)\end{array}$ & $\begin{array}{l}\text { Controls } \\
\text { (246) }\end{array}$ & & \\
\hline$<5$ & $\begin{array}{l}21 \\
(38.9 \%)\end{array}$ & $\begin{array}{l}23 \\
(9.3 \%)\end{array}$ & $\begin{array}{l}44 \\
(14.7 \%)\end{array}$ & \multirow{2}{*}{$<0.001$} \\
\hline$>5$ & $\begin{array}{l}33 \\
(61.1 \%)\end{array}$ & $\begin{array}{l}223 \\
(90.7 \%)\end{array}$ & $\begin{array}{l}256 \\
(85.3 \%)\end{array}$ & \\
\hline \multirow{2}{*}{$\begin{array}{l}\text { APGAR } \\
\text { score at } 5 \\
\text { minutes }\end{array}$} & Status & & & \multirow{2}{*}{$\begin{array}{l}\mathrm{P} \\
\text { value }\end{array}$} \\
\hline & $\begin{array}{l}\text { Cases } \\
(\mathrm{n}=54)\end{array}$ & $\begin{array}{l}\text { Controls } \\
\text { (246) }\end{array}$ & Total & \\
\hline$<7$ & $\begin{array}{l}11 \\
(20.4 \%)\end{array}$ & $\begin{array}{l}12 \\
(4.9 \%)\end{array}$ & $\begin{array}{l}23 \\
(7.7 \%)\end{array}$ & \multirow{2}{*}{$<0.001$} \\
\hline$>7$ & $\begin{array}{l}43 \\
(79.6 \%)\end{array}$ & $\begin{array}{l}234 \\
(95.1 \%)\end{array}$ & $\begin{array}{l}277 \\
(92.3 \%)\end{array}$ & \\
\hline
\end{tabular}

Table 8: APGAR score at 1 and 5 minutes in MSAF.

\begin{tabular}{|c|c|c|c|c|}
\hline \multirow{2}{*}{$\begin{array}{l}\text { APGAR } \\
\text { score at } 1 \\
\text { minute }\end{array}$} & \multicolumn{2}{|c|}{ Cases $(n=54)$} & \multirow[b]{2}{*}{ Total } & \multirow{2}{*}{$\begin{array}{l}P \\
\text { value }\end{array}$} \\
\hline & Thin & Thick & & \\
\hline$<5$ & $\begin{array}{l}12 \\
(31.6 \%)\end{array}$ & $\begin{array}{l}9 \\
(56.2 \%)\end{array}$ & $\begin{array}{l}21 \\
(38.9 \%)\end{array}$ & \\
\hline$>5$ & $\begin{array}{l}26 \\
(68.4 \%)\end{array}$ & $\begin{array}{l}7 \\
(43.8 \%)\end{array}$ & $\begin{array}{l}33 \\
(61.1 \%)\end{array}$ & 0.09 \\
\hline \multirow{2}{*}{$\begin{array}{l}\text { APGAR } \\
\text { score at } 5 \\
\text { minutes }\end{array}$} & \multicolumn{2}{|c|}{ Cases $(n=54)$} & & \multirow{2}{*}{$\begin{array}{l}\mathrm{P} \\
\text { value }\end{array}$} \\
\hline & Thin & Thick & Total & \\
\hline$<7$ & $\begin{array}{l}5 \\
(13.2 \%)\end{array}$ & $\begin{array}{l}6 \\
(37.5 \%)\end{array}$ & $\begin{array}{l}11 \\
(20.4)\end{array}$ & \multirow{2}{*}{$\begin{array}{l}0.04 \\
3\end{array}$} \\
\hline$>7$ & $\begin{array}{l}33 \\
(86.8 \%)\end{array}$ & $\begin{array}{l}10 \\
(62.5 \%)\end{array}$ & $\begin{array}{l}43 \\
(79.6 \%)\end{array}$ & \\
\hline
\end{tabular}

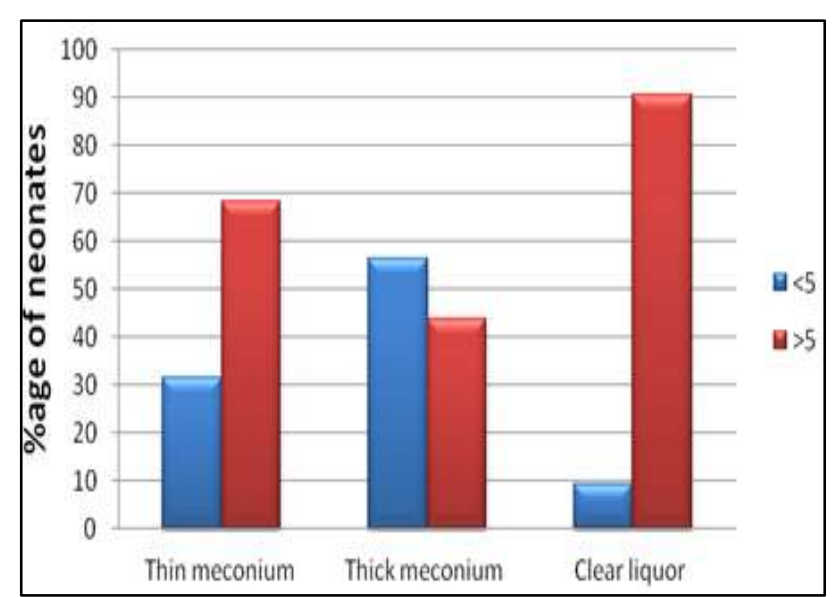

Figure 4: APGAR Score at 1 minute.

Low Apgar score at 1 and 5 minutes is noted in MSAF and is more often noted in cases with thick meconium. Low APGAR score was noted in $56 \%$ and $37.5 \%$ at 1 and 5 minutes respectively in cases with thick meconium compared to cases with thin meconium with low APGAR score in $31.6 \%$ and $13 \%$ at 1 and 5 minutes respectively which is statistically significant ( $\mathrm{p}$ value of 0.043 ).

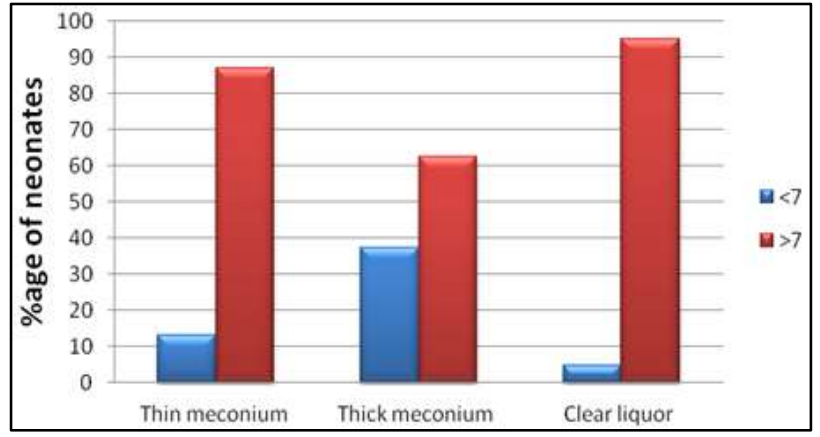

Figure 5: APGAR Score at 5 minutes.

Table 9: Requirement for Oropharangeal Suction.

\begin{tabular}{|llll|}
\hline $\begin{array}{l}\text { Oropharangeal } \\
\text { suction }\end{array}$ & Cases $(\%)$ & $\begin{array}{l}\text { Controls } \\
(\%)\end{array}$ & P value \\
\cline { 1 - 3 } Required & $32(59.26)$ & $46(18.7)$ & $<0.001$ \\
\hline Not required & $22(40.74)$ & $200(81.3)$ & \\
\hline
\end{tabular}

Oropharangeal suction was done in 32 babies $(59.26 \%)$ in cases against 46 babies $(18.70 \%)$ in control group with a $\mathrm{p}$ value $<0.001$. Oropharangeal suction was done in all the babies with thick meconium. Among the thin meconium cases and controls, Oropharangeal suction was done only in those babies who were relatively depressed.

Table 10: Incidence of NICU Admission.

\begin{tabular}{|lllll|}
\hline \multirow{2}{*}{$\begin{array}{l}\text { NICU } \\
\text { admission }\end{array}$} & $\begin{array}{l}\text { Cases } \\
(\mathrm{n}=53)\end{array}$ & $\begin{array}{l}\text { Controls } \\
(245)\end{array}$ & Total & $\begin{array}{l}\text { P } \\
\text { value }\end{array}$ \\
\cline { 1 - 3 } Needed & 13 & 14 & 27 & \\
& $(24.5 \%)$ & $(5.7 \%)$ & $(9.1 \%)$ & $<0.0$ \\
\cline { 1 - 3 } Not needed & $\begin{array}{l}40 \\
(75.5 \%)\end{array}$ & $\begin{array}{l}231 \\
(94.3 \%)\end{array}$ & $\begin{array}{l}271 \\
(90.9 \%)\end{array}$ \\
& & & & \\
\hline
\end{tabular}

NICU admission was frequent in cases and was needed in $24.5 \%$ of cases compared to $5.7 \%$ of controls. The difference is highly significant with $\mathrm{p}$ value of $<0.001$.

Table 11: NICU admission in cases.

\begin{tabular}{|c|c|c|c|c|}
\hline \multirow{2}{*}{$\begin{array}{l}\text { NICU } \\
\text { admission }\end{array}$} & \multicolumn{2}{|c|}{ Type of meconium } & \multirow{2}{*}{ Total } & \multirow{2}{*}{$\begin{array}{l}P \\
\text { value }\end{array}$} \\
\hline & Thin & Thick & & \\
\hline Needed & $\begin{array}{l}6 \\
(15.8 \%)\end{array}$ & $\begin{array}{l}7 \\
(46.7 \%)\end{array}$ & $\begin{array}{l}13 \\
(24.5 \%)\end{array}$ & \multirow[b]{2}{*}{0.019} \\
\hline $\begin{array}{l}\text { Not } \\
\text { needed }\end{array}$ & $\begin{array}{l}32 \\
(84.2 \%)\end{array}$ & $\begin{array}{l}8 \\
(53.3 \%)\end{array}$ & $\begin{array}{c}40 \\
(75.5 \%)\end{array}$ & \\
\hline
\end{tabular}

On comparing the thin and thick subgroups, it was the thick subgroup with high incidence of NICU admission. Nearly half of the cases with thick meconium needed NICU admission and only $15.8 \%$ of cases with thin meconium needed NICU admission.

Perinatal complications was seen in 13 cases out of which 3 developed MAS ,6 developed HIE,2 babies developed 
sepsis, 1 needed mechanical complications and 1 was a fresh still birth.

There were 4 neonatal births, 3 in thick meconium and 1 in thin meconium group. Causes of death were MAS, HIE, persistent pulmonary hypertension, cardiac failure, disseminated, intravascular, coagulation, and pneumothorax.

\section{DISCUSSION}

In the present observational study, various parameters were assessed to find out effect of meconium stained liquor on mode of delivery and immediate fetal outcome. Three hundred pregnant women were enrolled in the study randomly fulfilling the inclusion criteria. Liquor characteristics were closely observed and women who had meconium stained liquor were labeled as cases and the rest were labeled controls. 54 out of 300 women had MSAF in our study which amounts to $18 \%$ incidence. Similar results were found in a study by Swain et al. ${ }^{6}$ In our study mean gestational age of cases was higher than controls $(\mathrm{p}=0.16)$. Mean gestational age of cases and controls is $39.73+/-1.2$ weeks and $39.18+/-2.8$ weeks respectively similar to findings of Khatun et al, Rosario et al, Mundhra et al. ${ }^{7-9}$

Fetal CTG abnormalities were more common in cases and were noted in $29.6 \%$ cases compared to $9.3 \%$ of controls in our study $(\mathrm{p}=<0.001)$. Our findings were consistent with findings of Gupta et al, Mundhra et al, Odongo. ${ }^{9-11}$

In our study, $40.7 \%$ of cases were delivered by LSCS, $46.3 \%$ by normal vaginal route and $13 \%$ needed instrumental delivery. In the control group, $65 \%$ delivered by normal vaginal route and LSCS was done in $26.4 \%$. The incidence of LSCS was higher in cases $(p=$ 0.037). Among the cases, the patients with thick meconium had higher incidence of LSCS (56.2\%) than in patients with thin meconium $(34.2 \%)$. Instrumental delivery was also more common in cases with thick meconium (18.8\%) than cases with thin meconium $(10.5 \%)$. Normal vaginal delivery occurred in only $25 \%$ of cases with thick meconium whereas $55.3 \%$ of cases with thin meconium were delivered by normal vaginal route. The reason for higher incidence of LSCS in our study among the cases was because of associated abnormal CTG findings especially in patients with thick meconium. Similar results were noted by Gupta et al, Naqvi et al, Khatun et al, Wong SF et al, Mundhra et al. $^{7,9,10,12,13}$

Apgar score was noted in all the babies at 1 minute and 5 minutes and resuscitation was done in non-vigorous babies with low APGAR score. One baby in each group had APGAR score of 0 at birth and after resuscitation in our study. Low APGAR score at 1 and 5 minutes was significantly more frequent in cases than controls with $(p=<0.001)$. In our study, low APGAR score at 1 minute occurred in $38.9 \%$ cases against $9.3 \%$ in controls whereas at 5 minutes $20.4 \%$ of cases had low APGAR score against $4.9 \%$ in controls $(\mathrm{p}=<0.001)$. our findings were consistent with findings by Gregory et al, Gupta et al. In our study, one minute Apgar score was less than 5 in $31.6 \%$ of thin meconium group and $56.2 \%$ in thick meconium group whereas 5 minute Apgar score was less than 7 in $13.2 \%$ of thin meconium group and $37.5 \%$ in thick meconium $(\mathrm{p}=0.043) .{ }^{10,14}$ Similarly, Tayade S, Altshuler et al. ${ }^{15,16}$ Oropharangeal suction was done in 32 babies $(59.26 \%)$ in cases against 46 babies $(18.70 \%)$ in control group in our study $(\mathrm{p}=<0.001)$. Oropharangeal suction was done in all the babies with thick meconium. Swain et al in their study performed oropharangeal suction in all cases,similar to findings of Khatun et al, Mundhra et al. In a study by Odongo et al there was no significant difference in the mean $24.5 \%$ of the cases were admitted in NICU whereas $75.5 \%$ of the cases did not require NICU admission in our study. ${ }^{6,7,9,11}$ Among controls only $5.7 \%$ needed NICU admission and $94.3 \%$ were asymptomatic at birth $(\mathrm{p}=<0.001)$. In a study by Mundhra et al $80 \%$ of babies among cases were asymptomatic at birth as compared to $93.16 \%$ babies in the controls group $(\mathrm{p}=<0.0001){ }^{10}$

Infants with MSAF had low Apgar scores at birth and $21.21 \%$ cases needed intensive care unit admissions against $8.42 \%$ in controls almost in close agreement with our study. On comparing the thin and thick MSAF cases, the thick meconium subgroup had high incidence of perinatal morbidity and $46.7 \%$ cases needed NICU admission against $15.8 \%$ babies in the cases with thin meconium. Our findings were similr to findings of Goud et al. ${ }^{15}$ In our study, $24.1 \%$ of babies in cases developed perinatal complications against $6.1 \%$ of babies in control group $(p=0.001)$. Subgroup with thick meconium had higher perinatal complications than thin subgroup $(\mathrm{p}=0.042)$. Complication rate was $6.1 \%$ in babies of control group against $15.8 \%$ in thin meconium cases and $43.8 \%$ in thick meconium cases.

Tayade $\mathrm{S}$ et al MAS incidence in MSAF cases in our study was $5.6 \%$ and was noted only in cases with thick meconium. ${ }^{15}$ In thick meconium subgroup, MAS was most common complication and $18.8 \%$ of the babies in thick subgroup developed it as a complication. Rossi et al incidence of MAS is varied in different studies. Swain et al, Gupta et al, Naqvi et al. ${ }^{6,10,12,17}$ In our study, perinatal asphyxia with HIE as a complication was seen in $11.1 \%$ of babies in cases against $3.7 \%$ of babies in controls.

In study by Gupta et al, Swain et al noted HIE in $6.66 \%$ of the cases similar to findings of Khatun et al. ${ }^{6,7,10}$ Comparing the mortality of the babies in cases and controls in our study, it was higher in the cases being $7.4 \%$ against $2.03 \%$ in controls. In the thick meconium subgroup, it was much higher whereas neonatal mortality of thin meconium subgroup (2.63\%) and controls $(2.03 \%)$ was similar to, Khatun et al, Gupta et al. ${ }^{7,10}$ 


\section{CONCLUSIONS}

From this study it is evident that meconium staining is a commonly observed phenomenon. As the presence of thick meconium is associated with increased perinatal morbidity and mortality, its presence should not be overlooked. The presence of meconium becomes more significant when it is associated with fetal heart rate abnormalities. Meconium aspiration syndrome is a significant cause of perinatal morbidity and mortality, which can be reduced by early detection, prompt delivery and neonatal resuscitation.

\section{Funding: No funding sources}

Conflict of interest: None declared

Ethical approval: The study was approved by the Institutional Ethics Committee

\section{REFERENCES}

1. Cunningham FG, Gant FN, Leveno KJ, Gilstrap LL, Hauth CJ, Wentrom DK. Williams Obstetrics. $21^{\text {st }}$ ed., McGraw-Hil; 2001.

2. Eriksen N, Hostetter M, Parisi V. Prophylactic amnioinfusion in pregnancies complicated by thick meconium. Am J Obstet Gynecol. 1994;170:344.

3. Miller FC, Sacks DA, Yeh SY. Significance of meconium during labour. Am J Obstet Gynecol. 1975;122:573-80.

4. Rapoport S, Buchanan DJ. The composition of Meconium; isolation of blood-group-specific polysaccharides; abnormal compositions of meconium in meconium ileus. Science. 1950;112(2901):150-3.

5. Mukhopadhyay PN, Naskar T, Dalui R, Hazra S, Guin K. Role of intrapartum amnioinfusion in meconium stained amniotic fluid. J Obstet Gynecol India. 2006;56(3):230-2.

6. Swain P, Thapalial A. Meconium stained amniotic fluid- a potential predictor of meconium aspiration syndrome. J Nepal Pediatr Soc. 2008;28(1):3-6.
7. Khatun M, Arzu J, Haque E, Kamal MA, Mamun $\mathrm{M}$, Khan $\mathrm{M}$ et al. Fetal outcome in deliveries with meconium stained liquor. Bangladesh J Child Health. 2009;33(2):41-5.

8. Rosario MC, Seshadri L. Meconium staining of amniotic fluid in low risk parturients. J Obstet Gynecol India. 1996;46:642-6.

9. Yoder BA, Kirsch EA, Barth WH, Gordon MC. Changing obstetric practices associated with decreasing incidence of meconium aspiration syndrome. Obstet Gynecol. 2002;99:731-9.

10. Kumari S, Gupta SN, Mahato IP, Giri R, Yadav A, Thakur A, et al. Health renaissance septemberdecember. 2012;10(3):198-202.

11. Odongo BE, Ndavi PM, Gachuno OW, Sequeira E. Cardiotocography and perinatal outcome in women with and without meconium stained liquor. East Afr Med J. 2010;87(5):199-204.

12. Naqvi SB, Manzoor S. Association of meconium stained amniotic fluid with perinatal outcome in pregnant women of 37-42 weeks gestation. Pak J Surg. 2011;27(4):292-8.

13. Wong SF, Chow KM, Ho LC. The relative risk of fetal distress in pregnancy associated with meconium-stained liquor at different gestation. Journal of Obstetrics and Gynecol. 2002;22(6):5949.

14. Gregory GA, Gooding CA, Phibbs RH, Tooley WH. Meconium aspiration in infants- a prospective study. J Pediatr. 1974;85:848-52.

15. Tayade S. The significance of meconium stained amniotic fluid- a cross sectional study in a rural setup. International Journal of Biomedical and Advance Research. 2012;03(12):861-6.

16. Altshuler G, Hyde S. Meconium-induced vasocontraction: a potential cause of cerebral and other fetal hypoperfusion and of poor pregnancy outcome. J Child Neurol. 1989;4:137-42.

17. Rossi EM, Philipson EH, Williams TG, Kalhan SC. Meconium aspiration syndrome: intrapartum and neonatal attributes. Am J Obstet Gynecol. 1989;161(5):1106-10

Cite this article as: Qadir S, Jan S, Chachoo JA, Parveen S. Perinatal and neonatal outcome in meconium stained amniotic fluid. Int J Reprod Contracept Obstet Gynecol 2016;5:1400-5. 